\title{
Discourses on Integration and Interaction in a Martial Arts Club
}

Madsen, Lian Malai

Published in:

Sports Governance, Development and Corporate Responsibility

Publication date:

2012

Document version

Early version, also known as pre-print

Citation for published version (APA):

Madsen, L. M. (2012). Discourses on Integration and Interaction in a Martial Arts Club. In B. Segaert, M.

Theeboom, C. Timmerman, \& B. Vanreusel (Eds.), Sports Governance, Development and Corporate

Responsibility (pp. 74-88). Routledge. Routledge Research in Sport, Culture and Society 
To appear in : "Sports Governance, Development and Corporate Responsibility"

Edited by Barbara Segaert, Marc Theeboom, Christiane Timmerman, Bart Vanreusel Routledge.

\section{Discourses on integration and interaction in a martial arts club}

Lian Malai Madsen

University of Copenhagen

\section{Introduction}

A recurrent theme in the public debate in contemporary Western Europe is cultural differences between ethnic minorities and majority populations. In the Danish debate, media presentations and political contributions regarding cultural diversity often involve stereotypical images of minority youth as a societal problem. According to the dominant discursive constructions by media and politicians, the solution to problems related to minority youth (such as educational underachievement or participation in criminal gang activities) is better integration. In addition, it is a widespread assumption among Danish politicians and practitioners in leisure associations that participation in organised recreational activities and sports clubs strengthens integration of culturally or socially marginalised youth into society (e.g. Anderson 2003, 2005, 2006, Boeskov \& Ilkjær 2005, Agergaard 2008, Madsen 2008). This ethnographic and interactional study of identity work among children and adolescents in a martial arts club in Copenhagen (Madsen 2008) contributes insights of relevance to a discussion of such assumptions.

Matters of linguistic conduct are central to discourses on cultural differences and integration. According to the dominating public and political perceptions of integration, cultural and linguistic minorities are required to learn the majority language and adapt to majority cultural practices to be 
considered well integrated (Jørgensen 2010: 108). Children and adolescents, in general, but in particular children and adolescents with minority background, are expected to acquire certain linguistic and social behaviours in order to be successfully socialised as good democratic citizens (e.g. Kristiansen 2003). In this paper, I discuss the understandings of integration processes reflected in sports-political initiatives and public discourses in Denmark. My discussion is based on the observed conduct of the young members of the martial arts club. I argue for the importance of not merely assuming that membership of a sports club will in itself lead to integration and social cohesion, but that different conditions for participation in the sports activities need to be taken into account, as well as the local social status relations within the club community. Furthermore, I illustrate that linguistic practice plays a significant part for integration processes on a micro-level. In this way, my work brings into focus how a sociolinguistic perspective considering microsociological aspects can fruitfully supplement research within the sociology of sports. After presenting my data and my approach (section 2), I discuss a type of discourse on diversity that has been particularly influential within the integration debate in Denmark. I point to general problematic aspects of the sports-political integration initiatives reflecting this type of dominating discourse (section 3). After this, I present my ethnographic analysis of social status relation and orientation in relation to the sports discipline within the club (section 4). Finally, before my concluding discussion (section 6), I present an example of how social processes that can be characterised as integration processes, are carried out on a micro-level in interactions among the young club members (section 5).

\section{Data and approach}

The data I discuss are collected for a study of identity work and language use among children and youth in a martial arts club in Copenhagen (Madsen 2008). From August 2004 to June 2005 I 
observed and collected data from 16 children and adolescents in a Taekwondo club with a highly diverse population of members. During the fieldwork period, the participants in my study formed five different friendship groups, two girl groups (girls 1: 11-12 years old and girls 2: 14-15 years old) and three boy groups (boys 1: 10-11 years old, boys 2: 12-13 years old and boys 3: 14-15 years old). The data consist of field notes, largely unstructured qualitative interviews with the groups and individuals, video-recorded group-conversations, and participants' self-recordings (only audio).

My research is driven by an interest in how social differentiation and identity categories make sense to the young members of the club. I have approached my data with an emphasis on what actually occurs in the data, how social categories are made relevant through linguistic acts, and how my findings resemble or differ from phenomena dealt with in existing research and theoretical accounts. In addition, I am concerned with how the conduct of the young club members relates to, reproduces, reinterprets, or resists influential ideas about cultural diversity and youth in contemporary Danish society. I employ the approach of interactional sociolinguistics, which has developed from the tradition of linguistic anthropology (Gumperz 1972, 1982, Kulick 1992, Ochs 1996, Rampton 1995, 2006). Within this approach, it is emphasised that social categories and structures are produced and reproduced in everyday life. Therefore, the starting point is the lived and the local realities, and these are related to larger-scale socio-cultural processes. Ethnography is a central element of interactional sociolinguistics and a major strength of the approach is the combination of the analytical frameworks provided by linguistics and the reflexive sensitivity required in ethnography. My starting point is the ethnographic and linguistic micro-analyses of situated interactions among the 16 young members of the Taekwondo club, and I relate the analyses of the situational negotiations of social meaning to broader processes of social stereotyping and dominating ideas manifest in so-called discourses. The discourses I relate my study to, specifically concern a 
pervasive emphasis on ethnic and cultural differences, integration as adaption, and the persisting understanding of particular youth groups as non-majority.

\section{Discourses on integration}

The notion of integration has been prominent in the Danish debate since the mid 1990s (Olwig \& Pærregaard 2007: 18). In 2002, the government (still in power 2011) even established a distinct Ministry of Integration. The webpage of the Ministry of Integration makes clear that this ministry deals with immigrants' and refugee's development towards becoming successful members of Danish society. From the written information and the links on the page, we can see that this involves participation in language courses, cultural courses, employment, education and taxpaying (see www.nyidanmark.dk). Yet, in the general debate as well as in much research on integration it is rather unclear what precisely the concept of integration refers to (Ejrnæs 2002). The far most dominating discourse in Danish media and current policy making, however, is an ethnocentric discourse on diversity (Yilmaz 1999: 180-81, Rennison 2009: 120-158). The ethnocentric discourse emphasises values related to culture and the view of integration within this discourse is assimilationist. Ethnic minorities are regarded as either 'un-adapted strangers' or 'disciplined strangers' if they are well integrated (Rennison 2009: 153), and the goal for integration is to reach mono-cultural coherence through assimilation of cultural minorities into the majority culture. The ethnocentric discourse on integration is not an exclusively Danish phenomenon, but characteristic of public debate and policy making in a range of Western European countries (e.g. Blommaert \& Verschueren 1998, Yilmaz 1999, Jaspers 2005, Extra et al. 2009). A significant aspect of the public and political integration debate is an assumed connection between participation in organised leisure activities and successful participation in society in general. 
Recent work within the sociology of sports document that it is a common assumption within sports as well as sports studies, that participation in organised recreational activities and sports clubs strengthens integration of minority and socially marginalised youth into majority society (e.g. Anderson 2003, 2005, 2006, Boeskov \& Ilkjær 2005, Agergaard 2008). The idea of sports activities potentially leading to social inclusion and more general societal benefits is internationally widespread (e.g. Bailey 2007, Hedstrom \& Gould 2004). However, it appears particularly salient in the Danish public discourse that the lack of participation in organised leisure activities in the form of club membership, which involves contact with adults, is considered symptomatic of problematic societal integration (Rambøll \& Andersen 2010: 32). One aspect of this idea is illustrated by the category 'foreningsl $\phi s e$ b $\phi r n '$ (club-less children) which figures in statistics signifying social problems (Anderson 2005: 168).

It is characteristic within the Taekwondo club that educational aspects and societal benefits of the sports activities are emphasised and valued. This is the case on an organisational level as well as among the young practitioners. A focus on elite development and competition is a central part of the club's identity, but at the same time the club frequently participates in local sports-political initiatives focusing on integration (for detailed discussion see Madsen 2008: chapter 1). In addition, several of the members of the club present the understanding that the competences and values achieved through Taekwondo, and the ideological aspects of the sport, lead to some form of social mobilisation when transferred to other areas of life. An example of this is presented here by the chief children's instructor:

'(...) well there've been many cases where where you can say partly there've been some cases who balanced on the border of becoming some terrible (0.5) criminals whom then through the 
Taekwondo sport through finding some friends here in the club or somebody they can look up to and being able to come here in the club and belong here and even though they have have done some shit then they've gotten gotten some chances and been helped by the club right like like a kind of family and then they've straighten up' (interview with chief children's instructor, my translation).

The children's instructor describes the means of development from 'bordering criminals' to 'straitened up' as a combination of the Taekwondo sport and the belonging to of a family-like community in the club. Yet, there are no interview reports on how these developments supposedly occur and how the belonging is achieved.

The Ministry of Integration has launched a number of initiatives focusing on integration of ethnic minorities through participation in sports clubs (the club participates in the initiative Get2Sport, see www.get2sport.dk). My observations in the Taekwondo club certainly suggest that the idea of integration through sports is well supported among the sports practitioners. However, my study in the martial arts club, points to aspects worth discussing further in relation to the understanding of integration as it is represented in such sports political initiatives. The integration projects typically aim for increasing the number of members (and sometimes instructors) with ethnic minority background in the clubs. These projects rarely take into consideration how exactly membership of a club leads to 'a community based on shared values and interest across ethnic, social, and political borders'(http://www.nyidanmark.dk/dadk/Integration/puljer/puljebeskrivelser/det_frivillige_integrationsarbejde_og_d eltagelse_i_idraets_og_foreningslivet). It is assumed that participants are accepted in a community of a club merely based on shared interests. Conditions for participation, community-based power relations, and processes of inclusion and exclusion within the community are thereby overlooked. In addition, it is characteristic that ways of orienting to sports skills as well as the relationship between 
sports skills and social status hierarchy in a given sports club are disregarded. Finally, and in tune with the general Danish integration debate, ethnicity and cultural differences are foregrounded as relevant to problems of integration. Political sports-related integration initiatives overwhelmingly focus on ethnic and cultural minorities gaining knowledge of and adapting to majority cultural practices.

My ethnographic and linguistic study informs a discussion of such common assumptions about membership of a sports club, by looking into details of the social processes actually occurring among the young martial arts practitioners. The study of social practices in the club, points to the importance of taking into consideration the community-constructed social hierarchies and the local processes of inclusion and exclusion. In the club, the local processes of inclusion and exclusion are not merely related to aspects of ethnicities and a much more complex picture appears when you attend to the subtlety of occurring practices. Hence, an interactional sociolinguistic perspective, taking into account situated linguistic constructions and sequences of interaction in combination with an analytical focus on a sports club as a social community make visible how formal membership in a sports club, involves a variety of different participant positions. These positions are constructed, ascribed, and negotiated among the members and they are associated with different social values allowing varying degrees of influence within the sports club.

\section{Identity-positionings in the club}

The positioning of individuals in a larger social community can be studied through ethnographic observation of regular practices of the participants. During the time I spend in the Taekwondo club, I observed certain patterns of behaviour of the five groups of friends in focus in my study. It became clear that a significant point of orientation within the social community of the club was 
ways of relating to the sports activities. Some participants engaged in practices related to a competitive dimension of the sport, while others predominantly engaged in social practices around the sports activity and were less focused on competitive skills of the sports discipline itself. This insight led me to carry out a systematic analysis of my ethnographic observations (including information gathered from interviews). The analysis takes into account the young club member's orientation towards the sports discipline, as well as the local power relations and social status differences between the young members. The characteristic practices of the groups related to membership status and Taekwondo orientation are summed up in table 4.1, where information on the participants' reports of their motivation for being members of the club is also added: 


\begin{tabular}{|c|c|c|}
\hline Group & Related to membership status & Related to Taekwondo orientation \\
\hline Boys 3 & $\begin{array}{l}\text { - } \\
\text { - } \quad \text { consider the club a 'second home' } \\
\text { - } \quad \text { referred to by } 10 \text { other participants } \\
\text { - } \quad \text { often referred to as coolest, most popular } \\
\text { members } \\
\text { - } \\
\text { interacted with many other (mostly male) } \\
\text { members }\end{array}$ & 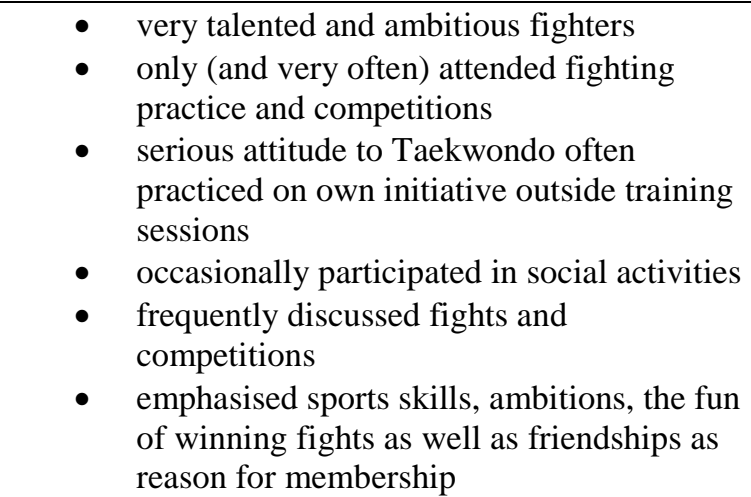 \\
\hline Boys 2 & $\begin{array}{ll}\text { - } & \text { spend a lot of time in the club } \\
\text { - } & \text { hung out in several different rooms } \\
\text { - } & \text { referred to by } 6 \text { other participants } \\
\text { - } & \text { interacted with many other (male) } \\
\text { members }\end{array}$ & 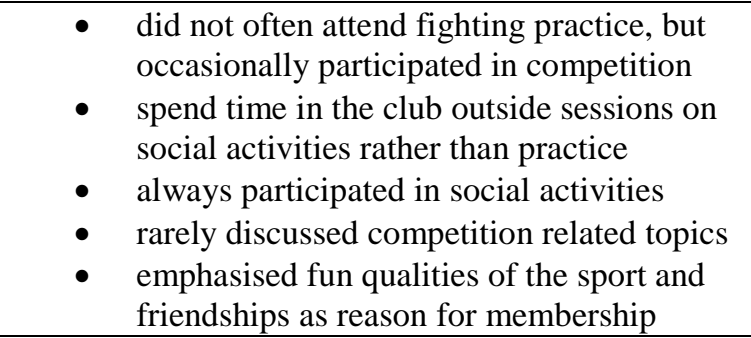 \\
\hline Boys 1 & $\begin{array}{ll}\text { - } & \text { spend quite a lot of time in the club } \\
\text { - } & \text { mostly stayed in café or training hall } \\
\text { - } & \text { only referred to by } 3 \text { participants } \\
\text { - } & \text { did not interact with many other members }\end{array}$ & 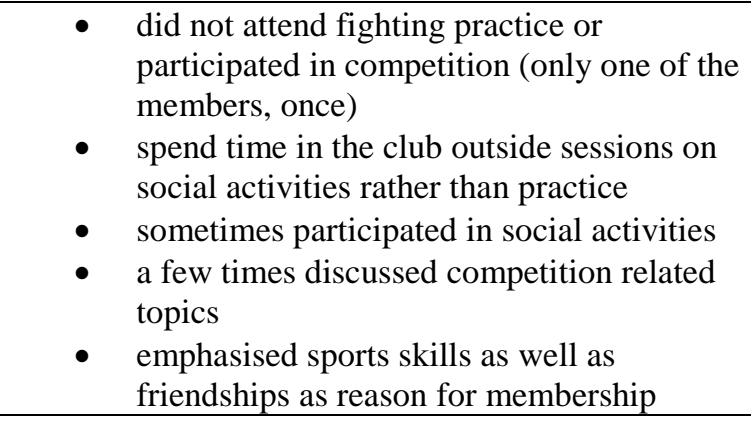 \\
\hline Girls 2 & $\begin{array}{l}\text { - } \text { did not spend much time in the club } \\
\text { outside training sessions, but some times } \\
\text { in the café } \\
\text { - } \quad \text { referred to by } 3 \text { participants } \\
\text { - did rarely interact with other young } \\
\text { members (often with adults) }\end{array}$ & $\begin{array}{l}\text { - } \text { often participated (or in in one of the girls' } \\
\text { case used to participate) in fighting practice } \\
\text { and competitions } \\
\text { - } \\
\text { - } \\
\text { - } \\
\text { occarely practiced outside training sessions } \\
\text { frequently discussed fights and } \\
\text { competitions } \\
\text { - } \\
\text { memphasised the fun of fighting as reason for } \\
\text { membersip }\end{array}$ \\
\hline Girls 1 & $\begin{array}{l}\text { - } \text { did not spend much time in the club } \\
\text { - } \\
\text { never spend time in the café, but stayed in } \\
\text { changing room and training hall } \\
\text { - } \quad \text { not referred to by any other club members } \\
\text { - never interacted with members outside } \\
\text { the girls' class }\end{array}$ & $\begin{array}{l}\text { - } \\
\text { - } \\
\text { - } \\
\text { spenper participated in fighting practice or } \\
\text { social activities rather than practice } \\
\text { - } \\
\text { participated in social activities around the } \\
\text { girls' class } \\
\text { - never discussed fights and competitions } \\
\text { emphasised cosy fellowship with girl } \\
\text { friends as important motivation for } \\
\text { membership }\end{array}$ \\
\hline
\end{tabular}

Table 4.1: Groups' characteristic practices related to membership status and Taekwondo orientation 
The social practices the participants engage in over time form their positioning in relation to other club members. Through the practices they signal affiliation or distance in relation to values and categories salient within the club (and often also on a larger social scale, for instance affiliation with streetwise hip hop-culture is more widespread). In this way participants on the one hand position themselves within the social community. On the other hand, participants are also positioned by others based on their conduct. Social positioning within a social community is crucial to processes of integration. No matter whether integration is understood as complete assimilation into a majority community or as some level of adaption by all participants involved, it is difficult to imagine any productive change in the conduct of an individual as related to an encounter with a particular community, if this individual is very marginally placed in relation to the community. Wenger's (1998) learning theory of communities of practice approaches these issues.

A community of practice refers to some collective of people engaging in some framework of doing. It is defined by participation through mutual engagement in a joint enterprise and through time the development of a shared repertoire of resources (Wenger 1998: 73). This definition very well covers a sports club community. Wenger (1998: 167) lists four main forms of participating in communities of practice: full participation (insider), full non-participation (outsider), peripheriality, and marginality. Both peripheral and marginal participation involve a combination of participation and non-participation. The difference between the two forms of participation is related to potential development through time, namely to the participation trajectory. Non-participation with respect to peripheral participants is enabling and an opportunity for learning. It is the position of newcomers to a community of practice and it entails the possibility of becoming full participants. We can imagine this form of trajectory as fruitful for integration Marginal participants conversely are restricted by non-participation. Marginality refers to long-standing members kept in a marginal 
position. Identity formation is influenced by the mix of participation and non-participation in the communities of practice we encounter. The mix of participation and non-participation, according to Wenger (1998: 167), reflects individuals' and communities' power to define and influence relations to the rest of the world. Identity formation has to do with our degree of investment in communities, but also our ability to shape the meanings defining these communities.

On the basis of the social practices characteristic of the groups (illustrated in table 4.1) it is possible to carry out an analysis that includes aspects of Wenger's theory of communities of practice. I have placed each group in the two-dimensional illustration in figure 1 according to their typical form of participation as well as their overall orientation in relation to the sports discipline (as competition or social fellowship). The horizontal axis represents a continuum between orientation towards casual social mutual participation in one end, and orientation towards competition in the other. In relation to the practices within the Taekwondo club, a high degree of orientation towards competition is signified by, for example, frequent participation in fighting practice, expression of competitive ambitions, participation in competitions, and frequent reference to these aspects of Taekwondo during interactions. Orientation towards casual social mutual participation is signified by the opposite: no participation in the fighting practice and the competitions, no reference to these aspects during interactions. Instead, members with this orientation are characterised by frequent participation in social activities and expression of friendship and social fellowship, as the main motivation for their participation in the community of practice. The vertical axis represents member's participation status in the community of practice, as a continuum between central members (toward Wenger's full participation) and marginal members. Central membership is characterised by a central placement within the social networks of the club and a high status within the social hierarchy. Marginal membership is characterised by the opposite. In principle, central 
membership can be obtained through both social and Taekwondo professional measures. Of course, this figure is a rather rough analytical abstraction of complex combinations of practices with individual variations. Nevertheless, the groups' positionings shed light on aspects of the relation between membership status and Taekwondo-orientation. Therefore, it provides an interesting foundation for the discussion of the social significance of various identity aspects in the community of practice.

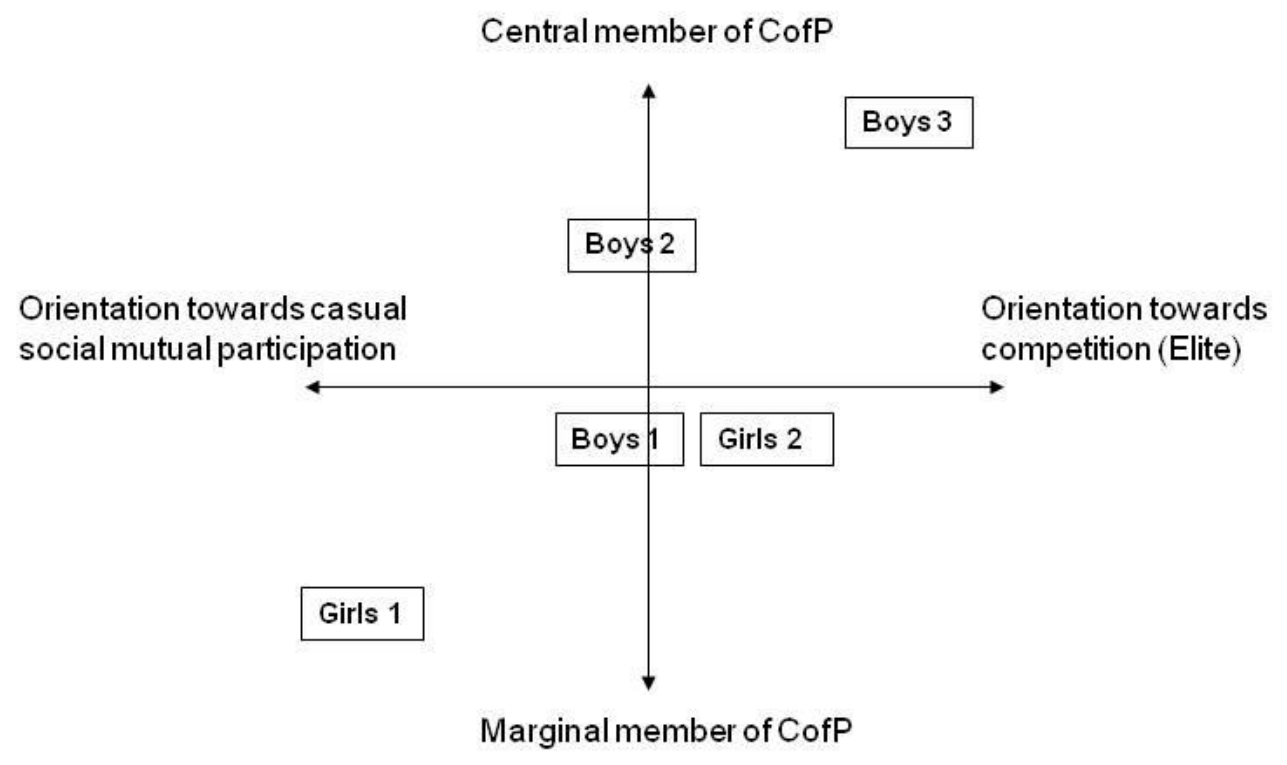

Figure 4.1: The groups' identity positionings

The oldest boys among the participants (boys 3) are positioned as very central members of the community of practice with strong orientation towards competition. The younger boys (boys 2) are positioned as central members oriented slightly more towards casual social mutual participation than competition. The youngest boys' (boys 1) positioning with respect to Taekwondo orientation is 
similar to the positioning of boys 2 , but they are positioned as more marginal members of the community of practice. The oldest girls among the participants (girls 2) are likewise positioned as rather marginal members, but they orient more towards competition than casual social mutual participation. Finally, the youngest girls (girls 1) are positioned as very marginal members with strong orientation towards casual social mutual participation. Figure 4.1 suggests that membership status in this community of practice relates to a combination of Taekwondo orientation, gender, and age. The participants in the most central social positions are the oldest among the young members, they are male, and they orient strongly towards competition. The participants in the most marginal social positions are the youngest of the female participants and they do not orient towards competition at all. Yet, central membership status does not correlate in a straightforward manner to any of these categories individually. The girls in group 2 are older, as well as more oriented towards competition than boys 2 , but they are positioned as more marginal members.

\section{Micro-integration in interaction}

We have seen how the employment of Wenger's (1998) concept of community of practice as an analytical unit brings into focus the need for much more nuanced considerations of what it entails to participate in a sports club. It is necessary to take into account what the conditions are for participation and how community-specific power relations may play a central part in relation to a sports club's potential as a site for socialising processes enhancing cohesion. I shall now turn to an example of a sequence of interaction where social processes that might be described as sociocultural integration, do take place on a micro-level. The extract 1 is an example of interactional behaviour typical of the oldest boys participating in my study. It is an exchange of utterances between Murat and Ilias which takes place 34 minutes into a self-recording, recorded on their way back to Copenhagen on the train after a regional elite fighter practice on the youth talent team. 
Murat carries the mp3-recorder. Salim, who is another talent team member (but not a participant in my study otherwise), is present as well. Just before this sequence, Salim has mentioned that he did a test exam in school earlier that day:

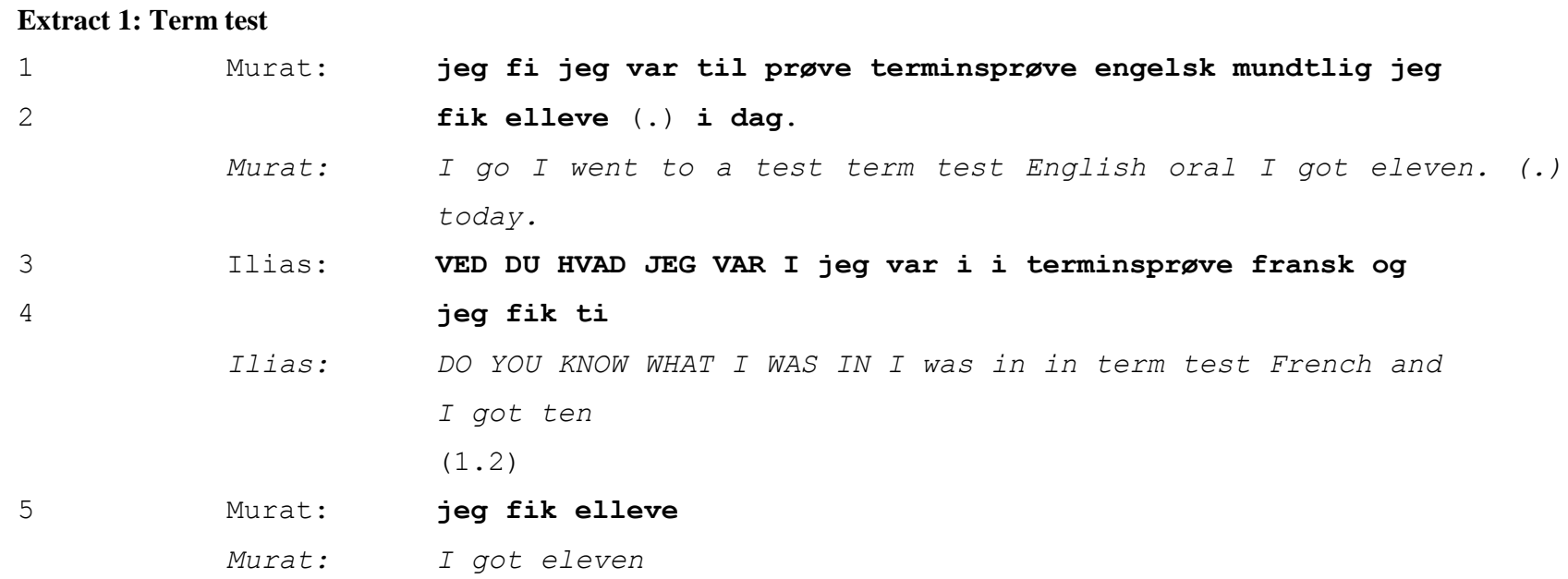

In these three utterances, Murat and Ilias explicitly claim linguistic competence by referring to or brag about recently achieved results of tests in foreign languages taught in Danish schools. In line 1-2 Murat tells the interlocutors that he received the mark eleven in a term test in English. Murat's utterance could be understood as merely offering information about the experience of the test, but Ilias' counter information (line 3-4) in a high volume suggests that he reacts to Murat's utterance as bragging. The sequential connection, the loud volume in Ilias' turn, and the described following comparative repetition of the test results (by Murat) frame the contributions, and thereby the contributors, in a competitive relationship. Both Murat and Ilias use a number of non-standard features associated with a late modern urban youth style of Danish (Madsen 2008). These include pronunciation without the Danish 'stød' in words like 'terminsprøve', 'engelsk', 'fransk' and 'ti'. The boys also leave out the preposition in 'terminsprøve engelsk' (term test English), and 'terminsprøve fransk' (term test French). Furthermore, Ilias uses the preposition 'i' (in) in a non- 
standard manner ('i terminsprøve', in term test). Finally, they both employ a pronunciation on the utterance level with a characteristic prosody (see Pharao \& Hansen 2006).

Thus, Murat and Ilias appear to be engaged in a situational (rather playful) fight over status in. The fight takes place during an interaction in an out-of-school context, and could be described as carried out through claims of school-related linguistic capital. The linguistic practice employed by the boys in this sequence, however, is not a practice typically appreciated in educational contexts. Their linguistic practice is characterised by the use of features associated with late modern urban youth style. The late modern urban youth style does not stereotypically connote academic success. The style could be said to represent informality, non-standard vernacular, and peer-socialising and in this sense contrasts with formal, mainstream-appreciated, and elite-societal connotations (see Madsen 2008). The use of the style in combination with school ambitious practices by the boys thus results in renegotiations of dominant norms of societal and school-related success being equated with linguistic standard practices. The boys manage situated identity constructions as successful, but non-nerdy students.

Extract 1, is of course only a single and short example, but it is highly characteristic of the behaviour of this group of boys. Sequences such as extract 1 illustrate at least two central points in relation to discourses on integration:

1) Negotiation of social status relations is central even to interactions among close friends. This underlines the significance of status relations to participation in social communities, and hence, to processes of integration. 
2) Processes of integration are not merely co-presence of diverse groups of individuals. Processes of integration involve micro-acts that bring about and integrate relations of different cultural frames (also, on a socio-symbolic level).

That the boys in their peer interactions demonstrate capability to navigate between the normative demands of peer-culture as well as majority cultural elite-expectations can of course not be directly attributed to their participation in a sports club (for instance we find similar episodes in data from boys practicing hip-hop music see Stæhr 2010, Madsen 2011). Still, it is likely that the leisure environment perhaps provides a less restricted social space than for instance a school context, and thereby leisure contexts might be considered particularly fruitful sites for these kinds of microintegrating identity practices.

\section{Concluding discussion}

In this paper I have argued that assumptions of participation in sports clubs as fruitful for integration are characteristic of public discourse, integration-political initiatives, as well as among practitioners in sports clubs. The dominating view of integration in current public discourse and policy in Denmark is assimilationist and this understanding appears reflected to some extend in the sports-political initiatives aimed at integration. This does not necessarily mean that practitioners in sports clubs participating in integration projects employ an assimilationist notion of integration in their work (we saw an example of a family-like belonging presented by an instructor). Nevertheless, it is characteristic on a political level as well as among practitioners in sports club that there is a lack of reflection on how integration processes are supposed to occur in club communities. The data I have discussed, add two significant points to discussions of integration through sports. Firstly, the observed conduct of the young members nuances dominating understandings of integration within 
the ethnocentric discourse. Secondly, the study in the martial arts club underlines the importance of considering local processes of social inclusion and exclusion in a sports club. This second point is of relevance to political initiatives, practitioners in sports clubs as well as sports studies concerned with socialising and educational aspects of sports.

With respect to the first point, the analyses of the interactional data presented in this paper make clear that the ideas of social integration, as they are presented in dominating stereotypical discourses, cannot account for what happens among the young club members. As we have seen, young minority boys within the frames of the recreational social site of a sports club, refer to measures of school success. Furthermore, the boys frequently employ non-standard linguistic resources in combination with the school-related interactional activities. Thereby they challenge stereotypical assumptions about an opposition between successful academic and successful urban, streetwise, masculine youth identities. Social integration in the sense that it is practiced interactionally among the boys does not merely involve adaptation to dominating measures of societal success, but involves bringing together different norms, values, and practices. The young speakers successfully manage norms of school success and socio-symbolic values among peers. They master integrated identity constructions of themselves as good students, skilled martial arts practitioners, and cool young urban boys of a high social status in the club community.

With respect to the second point, I have demonstrated how formal membership in a sports club, involves a variety of different participant positions and how the different positions are associated with different social value allowing varying degrees of influence within the community of practice. The study in the martial arts club points to the importance of taking into consideration the community-constructed power hierarchies. In the club (as we saw in figure 4.1), there is a great 
difference between participating as an 11-year-old girl practicing in the girls' class, and practicing as a 15-year-old boy on the elite fighting team. Although all of the participants in the study were longstanding members, in particular the girls, and those who did not engage in competition fighting, remained marginal participants. The analysis of the social practices of the young club members underlines that considering a sports club a potential socialising and unifying community requires accounts of the local processes of integration into the community of practice of the club and the social negotiations involved in these processes.

\section{References}

Agergaard, S. (2008). Unges idratsdeltagelse og integration i idratsforeninger i Århus Vest .Copenhagen: Idrættens analyseinstitut.

Anderson, S. (2003). Civilizing Children: Children's Sports and Civil Sociality in Copenhagen, Denmark. PhD dissertation. Copenhagen: Institute for Anthropology.

Anderson, S. (2005).' "Vi kender hinanden alle sammen hvor vi så end er fra" At leve lokalt gennem global sport i København’. In Karen Fog Olwig, Laura Gilliam \& Karen Valentin (eds.) Lokale liv fjerne forbindelser. Studier af børn, unge og migration. Copenhagen: Hans Reitzel, pp. 153-174.

Anderson, S. (2006). 'Storbymennesker. Tilflyttere og lokale i københavnske kampsportsklubber' in M. Rytter \& M. Holm Pedersen (eds.) Den stille integration. Nye fortcellinger om at høre til $i$ Danmark. Copenhagen: C.A. Reitzel, pp. 63-91. 
Bailey, R. (2007). 'Youth sport and social inclusion' in N.Holt (ed) Positive Youth Development through Sport. London: Routledge, pp. 85-97.

Blommaert, J. \& J. Verschueren (1998). Debating diversity: Analysing the discourse of tolerance.

London: Routledge

Boeskov, S. \& Ilkjær, T. (2005). Integration og det frivillige foreningsliv. En unders $\phi$ gelse af barrierer og lфsninger i relation til foreningsdeltagelse hos unge med anden etnisk baggrund. Copenhagen: Department of sports studies. University of Copenhagen.

Ejrnæs, M. (2002). Etniske minoriteters tilpasning til livet i Danmark-forholdet mellem majoritetssamfund og etniske minoriteter, AMID Working Paper Series 18/2002.

Extra, G., M. Spotti \& P. Van Avermaet (Eds.) (2009). Language Testing, Migration and Citizenship: Cross National Perspectives on Integration Regimes. London: Continuum.

Gumperz, J. (1972). 'Introduction' in J. Gumperz \& D. Hymes (eds.) Directions in Sociolinguistics: The Ethnography of Communication. London: Blackwell, pp. 1-25.

Gumperz, J. (1982). Discourse Strategies. Cambridge: Cambridge University Press.

Hedstrom, R. \& D. Gould (2004). Research in Youth Sports: Critical Issues Status. Michigan: Michigan State University. 
Jørgensen, J. N. (2010). Languaging. Nine years of poly-lingual development of young TurkishDanish grade school students. Copenhagen: Danish School of Education, University of Aarhus.

Kristiansen, T. (2003). 'Language attitudes and language politics in Denmark' in International Journal of the Sociology of Language 159, pp. 57-71.

Kulick, D. (1992). Language Shift and Cultural Reproduction: Socialization, Self, and Syncretism in a Papua New Guinean Village. Cambridge: Cambridge University Press.

Madsen, L. M. (2008). Fighters and Outsiders. Linguistic practices, social identities, and social relationships among urban youth in a martial arts club. University of Copenhagen.

Madsen, L. M. (2011). 'Interactional renegotiations of educational discourses in recreational learning contexts' in Linguistics ad Education 22 (1), pp. 53-67.

Ochs, Elinor (1996): 'Linguistic resources for socialising humanity' in J. Gumperz and S. Levinson (eds.) Rethinking Linguistic Relativity. Cambridge: Camdridge University Press, pp. 438-469.

Olwig, K. Fog \& K. Pærregaard (eds) (2007). Integration. Antropologiske perspektiver. Copenhagen: Museum Tusculanums Forlag.

Pharao, N. \& G. Foget Hansen (2006). Prosodic aspects of the Copenhagen Multiethnolect. In Nordic prosody. Proceedings of the IXth Conference, Lund 2004: Peter Lang, pp. 87-96. 
Rambøll Management Consulting \& S. Calmar Andersen (2010). Mehmet og modkulturen. En undersфgelse af drenge med etnisk minoritetsbaggrund Copenhagen: Rambøll.

Rampton, B. (1995): Crossing. Language and ethnicity among adolescents. London:

Longman.

Rampton, B. (2006). Language in Late Modernity. Interaction in an urban school. Cambridge:

Cambridge University Press.

Rennison, B. W. (2009). Kampen om integrationen: Diskurser om etnisk mangfoldighedsledelse . Copenhagen: Hans Reitzel.

Stæhr, A. (2010). Rappen reddede os. Et studie af senmoderne storbydrenges identitetsarbejde $i$ fritids- og skolemiljøer. Copenhagen: University of Copenhagen.

Wenger, E. (1998). Communities of practice. Learning, Meaning and Identity. Cambridge: Cambridge University Press.

Yilmaz, F. (1999). 'Konstruktionen af de etniske minoriteter: Eliten, medierne og 'etnificering' af den danske debat' in Politica, 31/2, pp. 2-24. 